\title{
Journal of Genetics Online Resources
}

\section{January - April 2013}

Hu X.-H., Ren L. and Chen X.-Y. 2013 Isolation and characterization of microsatellite loci for acorn weevil Curculio bimaculatus Faust (Coleoptera: Curculionidae). J. Genet. 92, e1-e3. Online only: http://www.ias.ac.in/jgenet/OnlineResources/92/e1.pdf

Nag A., Bhardwaj P., Ahuja P. S. and Sharma R. K. 2013 Identification and characterization of novel UniGene-derived microsatellite markers in Podophyllum hexandrum (Berberidaceae). J. Genet. 92, e4-e7. Online only: http://www.ias.ac.in/jgenet/OnlineResources/92/ e4.pdf

Sun Y., Xue J., Guo W., Li M., Huang Y., Lan X., Lei C., Zhang C. and Chen H. 2013 Haplotypes of bovine FoxOl gene sequence variants and association with growth traits in Qinchuan cattle. J. Genet. 92, e8-e14. Online only: http://www.ias.ac.in/jgenet/ OnlineResources/92/e8.pdf

Yee E. Y. S., Zainuddin Z. Z., Ismail A., Yap C. K. and Tan S. G. 2013 Molecular sex identification of painted storks (Mycteria leucocephala): using FTA cards, horizontal PAGE and quick silver staining. J. Genet. 92, e15-e18. Online only: http://www.ias.ac.in/ jgenet/OnlineResources/92/e15.pdf

Qu C.-M., Liang X.-F., Huang W., Zhao C., Cao L., Yang M. and Tian C.-X. 2013 Development and characterization of twenty-nine novel polymorphic microsatellite loci in the mandarin fish Siniperca chuatsi. J. Genet. 92, e19-e23. Online only: http://www.ias.as.in/ jgenet/OnlineResources/92/e19.pdf

Datta S., Singh P., Mahfooz S., Patil G. P., Chaudhary A. K., Agbagwa I. O. and Nadarajan N. 2013 Novel genic microsatellite markers from Cajanus scarabaeoides and their comparative efficiency in revealing genetic diversity in pigeonpea. J. Genet. 92, e24-e30. Online only: http://www.ias.ac.in/jgenet/OnlineResources/92/e24.pdf

\section{STATEMENT ABOUT OWNERSHIP AND OTHER PARTICULARS ABOUT JOURNAL OF GENETICS}

1. Place of publication Bangalore

2. Periodicity of publication

3. Printer's name

4. and 5. Publisher and Editor

6. Nationality

7. Address

8. Name and address of the Owner
Bangalore

Three issues a year

R. Ramaswamy Indian Academy of Sciences Bangalore 560080

R. Ramaswamy

Indian

Indian Academy of Sciences P. B. No. 8005

Bangalore 560080

Indian Academy of Sciences

P. B. No. 8005

Bangalore 560080

I, R. Ramaswamy, hereby declare that the particulars given above are true to the best of my knowledge.

Dated 1 March 2013

R. Ramaswamy

Signature of Publisher 